\title{
ARRB1 wt Allele
}

National Cancer Institute

\section{Source}

National Cancer Institute. ARRB1 wt Allele. NCI Thesaurus. Code C52462.

Human ARRB1 wild-type allele is located in the vicinity of $11 q 13$ and is approximately 86 $\mathrm{kb}$ in length. This allele, which encodes beta-arrestin-1 protein, plays a role in the desensitization of beta-adrenergic receptor signaling. 